\title{
Placenta Growth Factor
}

National Cancer Institute

\section{Source}

National Cancer Institute. Placenta Growth Factor. NCI Thesaurus. Code C28666.

Placenta growth factor (221 aa, $25 \mathrm{kDa}$ ) is encoded by the human PGF gene. This protein is involved in both angiogenesis and the positive regulation of endothelial cell growth. 